\title{
Genetic status of Centella asiatica (L.) Urb. (Indian pennywort): A review
}

\author{
Sakthipriya Mathavaraj, Kalluvettankuzhy Krishnannair Sabu* \\ Jawaharlal Nehru Tropical Botanic Garden and Research Institute (JNTBGRI), Palode, Thiruvananthapuram 695562, \\ Kerala, India
}

\author{
Received: March 09, 2021 \\ Revised: August 20, 2021 \\ Accepted: August 24, 2021 \\ Published: September 10, 2021 \\ *Corresponding author: \\ K. K. Sabu \\ E-mail:sabu@jntbgri.res.in
}

\begin{abstract}
In recent years, demand for medicinal plants increased due to the rise in attraction towards herbal products which are safer compared to modern drugs. Centella asiatica (L.) Urb is known as an important medicinal plant in herbal medicinal systems. It is also used as an active ingredient for many products in the pharmaceutical and cosmetic industry. So far, review on this plant concerns mainly on medicinal, cosmetology and photochemical works reported. This review presents the genetic studies conducted on this herb along with a mention of conservation. Since documenting and studying genetic variation and its composition has an important connection for the understanding of evolution and improving the conservation of this species.
\end{abstract}

KEYWORDS: Genetic diversity, medicinal plant, genetic marker, herbal medicine, conservation

\section{INTRODUCTION}

Apiaceae family is generally well-known for vegetables, medicinal and flavoring plants. Centella asiatica (L.) Urb, comes under this flowering family which is an important medicinal and vegetable herb that has a significant position in the trading market. Mostly secondary metabolites in plants are used as food additives, drugs, pesticides and pigments. Generally, molecular markers based methods are essential to study diversity, classify species, identifying adulteration, predict gene flow and track the trait loci in the plant for breeding and genetic improvement (Neelima, 2017).

Many medicinal plant species we use commonly are mostly harvested from the wild but its conservation, improvement in cultivation and breeding are not targeted when compared to the importance given to crop plants. C. asiatica is one such medicinal herb that requires proper wise utilization, conservation and improvement at the genetic level. This moisture loving prostrate herb widely utilized in diverse fields such as pharmaceutical, dermatological, cosmetic, traditional and ayurvedic medicinal preparations is largely considered as brain food and panacea (Ravi et al., 2019).

For industry and commercial purposes, C. asiatica is mostly collected from the wild and natural resources; hence to ensure sustainable utilization it is necessary to have organized commercial cultivation and also its biomass and biosynthesis of compounds influenced by genotype $(G)$ x environmental (E) are to be evaluated to make improvements in this species. The above mentioned require initially proper documentation and understanding of this species genetic variation. This review gives a summary of genetic and genomic studies in C. asiatica to help in genetic improvement and conservation.

\section{DISTRIBUTION, DEMAND, USES}

Centella asiatica (L.) Urb. (Figure 1), also generally known as Gotu kola, Asiatic pennywort, Indian pennywort, Tiger herb or Spade leaf. It is a perennial herb, prostrate, faintly aromatic, stoloniferous and creeping runner. It is diploid with $2 \mathrm{n}=2 \mathrm{x}=18$, but some studies reported the presence of $\mathrm{B}$ chromosomes (Das \& Mallick, 1991) and tetraploid (Kokubugata et al., 1998). Reproduce is through seeds and vegetation propagation. It is distributed in the regions of Southeast Asia (Cambodia, Indonesia, Malaysia, Vietnam, Thailand, Singapore, the Philippines, Myanmar, Laos, Christmas Island and the Andaman Islands), Oceania, Africa, America, China, India, Sri Lanka, Pakistan, Madagascar, South East USA, Mexico, Pacific Islands, Australia, Venezuela, Columbia, Nepal etc (CABI, 2020) (Figure 2).

Over three thousand years ago, C. asiatica is being used as a "panacea” in India, China, Philippines, Africa, Madagascar and Sri Lanka. In the world, Madagascar is the top C. asiatica producer. In Southeast Asia, it has been used in the treatment of

Copyright: (C) The authors. This article is open access and licensed under the terms of the Creative Commons Attribution License (http://creativecommons.org/licenses/by/4.0/) which permits unrestricted, use, distribution and reproduction in any medium, or format for any purpose, even commercially provided the work is properly cited. Attribution — You must give appropriate credit, provide a link to the license, and indicate if changes were made. 


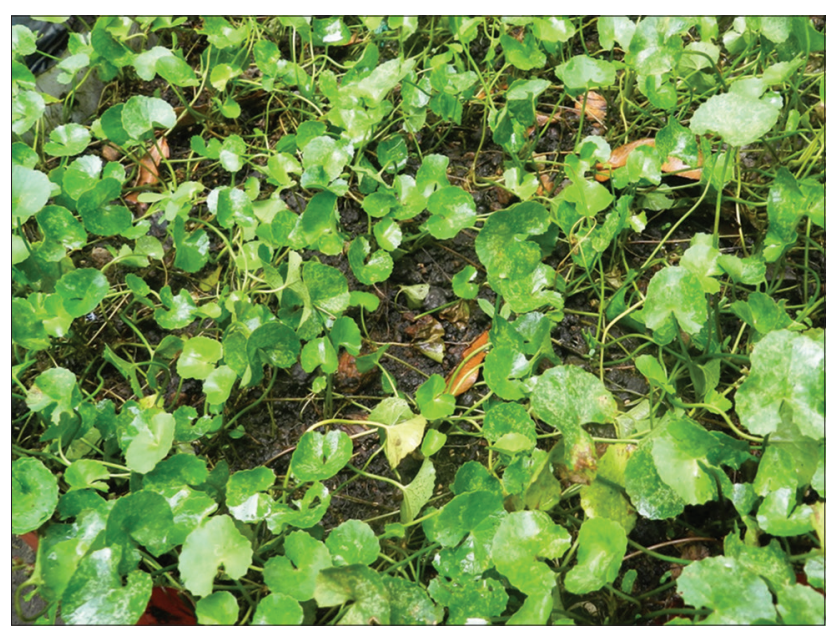

Figure 1: Habit of Centella asiatica at JNTBGRI experimental field

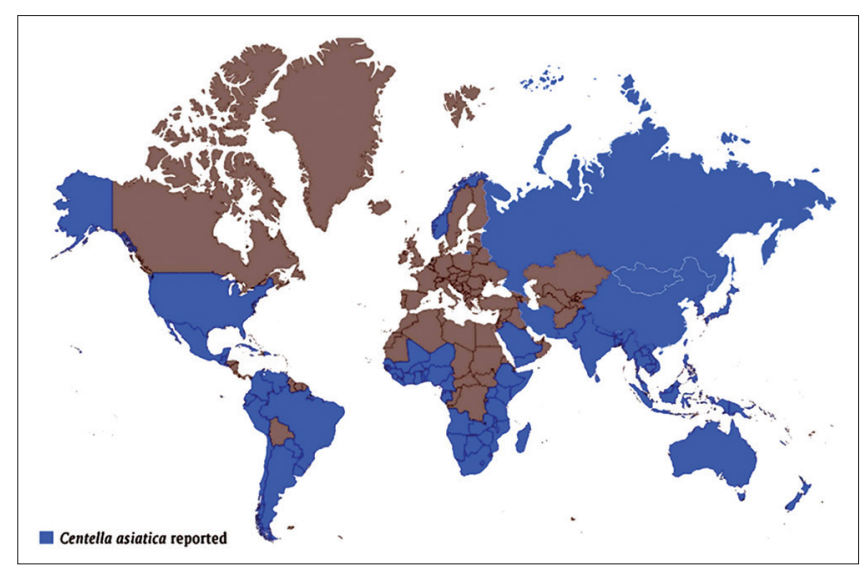

Figure 2: Distribution map of Centella asiatica reported

many problems such as rheumatism, skin diseases, inflammation, mental illness, syphilis, diarrhoea, epilepsy, dehydration and hysteria. In Europe, it was utilized in the treatment of wounds and ulcers. In traditional Asian medicine, C. asiatica has been used for hundreds of years, chiefly in dermatological conditions to get better from burns, small wounds, hypertrophic wounds and scratches. It is also suggested as an anti-inflammatory agent, mostly in eczema, in the treatment of vein insufficiency, antipyretic, anti-cancer agent, diuretic, an antibacterial, rheumatic, antiviral drug, for improving cognition and useful in relieving anxiety (Sudhakaran, 2017).

The efficacy of C. asiatica is due to the presence of pentacyclic ursane type triterpenoid centellosides such as madecassoside, madecassic acid, asiaticoside and asiatic acid. Due to the presence of immense medicinal properties, this plant was incorporated into many Pharmacopoeias. In the $19^{\text {th }}$ century, C. asiatica was included in the Indian Pharmacopoeia and many others included viz. European Pharmacopoeia VI, Chinese Pharmacopoeia, Homöopathisches Arzneibuch, Dutch Pharmacopoeia, British Herbal Pharmacopoeia, La Farmacopea Italiana X, German Pharmacopoeia, Polish Pharmacopoeian Martindale European Pharmacopoeia and Pharmacopee française (Bylka et al., 2013). It has great demand in the trade market, according to the United States market status C. asitaica comes in the list of top 25 selling medicinal plants and comes under the category of one of the top eight best selling herbs in the USA and Europe (Rohini et al., 2019). According to the Indian Medicinal Plants Database, all plant parts of C. asiatica (Sankrit name: Mandukaparni Brahmi) (National Medicinal Plants Board, 2015) as Brahmi booti in India and it was listed as a highly traded herb (estimated annual trade 500-1000 MT; sale at the rate of 30-35 Rupees per Kg).

\section{GENETIC STUDIES EXPLORED THE C. ASIATICA GENOME}

During the past years, many genetic works were conducted on this species to know about its genetic structure. The researchers used various genetic markers (Table 1) to study the C. asiatica genome and many genes were characterized. Recently, nextgeneration sequencing technology was used to explore genome size. In this status, the present review provides an overview of the genetic works in C. asiatica.

Genetic mapping can be used as a first step towards the improvement and efficient breeding of plants including medicinal plants where genetic markers play a key role. The difference among individual plants generally lies in the "genetic material”, i.e. DNA (deoxyribonucleic acid). The specific region in the chromosomes is responsible for specific characters which are termed genes. After the discovery of sequencing, it was easy to identify those character responsible regions in chromosomes. But still, several researchers are using the indirect method for identifying those regions called genetic markers (Agarwal et al., 2008; Semagn et al., 2006; Sharma et al., 2018).

Genetic markers are not a recent discovery since it was used during the nineteenth century by Gregor Mendel. He used phenotype-based genetic markers in his experiment. Genetic markers can be used to distinguish individuals by representing the genetic differences in the genome. After the discovery of polymerase chain reaction (PCR) by Kary Banks Mullis in 1983, several marker systems arise to play a key role in molecular research. PCR based molecular markers reduce the effort, expense and time required for molecular mapping. Now a day's SSR and SNP-based GMMs (genic molecular markers) are the most preferred markers for studying genetics and breeding plants even though other various markers like ISSR, RAPD, and AFLP etc., are easily available (Al-Samarai \& Al-Kazaz, 2015; H. Chen et al., 2017; Collard et al., 2005; P. K. Gupta et al., 1999; Joshi et al., 1999; P. Kumar et al., 2009; Semagn et al., 2006; Sharma et al., 2018; Srivastava et al., 2009).

\section{Randomly Amplified Polymorphic DNA (RAPD)}

RAPD was used to assess genetic variation in populations and to find the phylogenetic relationship among species/ subspecies and cultivars and to the construction of genetic linkage map (P. K. Gupta et al., 1999; P. Kumar et al., 2009; Welsh \& McClelland, 1990; Williams et al., 1990). C. asiatica plants have been mostly explored by these markers initially. 
Table 1: Summary of genetic studies in Centella asiatica using molecular markers

\begin{tabular}{|c|c|c|c|c|}
\hline $\begin{array}{l}\text { Type of } \\
\text { Marker }\end{array}$ & $\begin{array}{l}\text { Samples/ } \\
\text { Accessions/ } \\
\text { Populations (Location) }\end{array}$ & Number of Primers & $\begin{array}{l}\text { Genetic parameters or indices and } \\
\text { Comments }\end{array}$ & References \\
\hline $\begin{array}{l}\text { 1.RAPD } \\
1.1\end{array}$ & 21 Ecotypes (Nepal) & $\begin{array}{l}\text { Out of } 21 \text { decamers, } 8 \\
\text { were used for analysis }\end{array}$ & $\begin{array}{l}81 \% \text { polymorphism showed by } 8 \text { primers, average } 4.37 \\
\text { polymorphic bands per primer, } 0.52-0.911 \text { Jaccard similarity } \\
\text { coefficient; RAPD PCR condition was standardized }\end{array}$ & $\begin{array}{l}\text { (Devkota, 2011; } \\
\text { Devkota et al., 2011) }\end{array}$ \\
\hline 1.2 & $\begin{array}{l}10 \text { Accessions (Kerala, Tamil } \\
\text { Nadu, India) }\end{array}$ & $\begin{array}{l}\text { Out of } 40 \text { decamers, } 4 \\
\text { used for analysis }\end{array}$ & $\begin{array}{l}\text { Average } 5 \text { bands per primer, } 0.71-0.88 \mathrm{Nei} \& \text { Li's coefficient ( } \\
\text { of similarity; Nagercoil (Tamil Nadu, India) and Ponmudi } \\
\text { accessions shared } 0.88 \text { similarity coefficient, Pattami } \\
\text { accession (Palakad, India) showed distinct cluster }\end{array}$ & (Krishnan et al., 2007) \\
\hline 1.3 & $\begin{array}{l}18 \text { Medicinal plant } \\
\text { species include C. asiatica } \\
\text { (Karnataka, India) }\end{array}$ & $\begin{array}{l}\text { Out of } 10 \text { primers, } \\
3 \text { primers used for } \\
\text { analysis }\end{array}$ & $\begin{array}{l}\text { 96.84\% polymorphism showed by } 3 \text { decamer primers, } \\
0.00-0.72 \text { Pairwise Nei \& Li's coefficient of similarity; } \\
\text { Analysis differentiated medicinal plants species into groups } \\
\text { (Chikkaswamy, 2015); Clusters indicated low gene in } \\
\text { different medicinal plant species (Radhika et al., 2012). }\end{array}$ & $\begin{array}{l}\text { (Radhika et al., 2012) } \\
\text { (Chikkaswamy, 2015) }\end{array}$ \\
\hline 1.4 & $\begin{array}{l}18 \text { Medicinal plant } \\
\text { species include } C \text {. asiatica } \\
\text { (Karnataka, India) }\end{array}$ & 13 primers & $\begin{array}{l}97.6 \% \text { polymorphism; } \\
\text { Analyzed species showed high genetic differentiation } \\
\text { coefficients (Gst) }\end{array}$ & $\begin{array}{l}\text { (Paramanik \& } \\
\text { Chikkaswamy, 2014) }\end{array}$ \\
\hline 1.5 & $\begin{array}{l}\text { Nine accession (Andra } \\
\text { Pradesh, India) }\end{array}$ & $\begin{array}{l}\text { Out of } 30 \text { primers, } 16 \\
\text { were used for analysis }\end{array}$ & $\begin{array}{l}87 \% \text { polymorphism, } 8.5 \text { average no. of bands per primers, } \\
\text { Mean genetic diversity } 2.6 \text {; Cluster result indicated no } \\
\text { correlation between genetic distance and geographical } \\
\text { distances (Distant accessions showed } 78 \% \text { similarity) }\end{array}$ & $\begin{array}{l}\text { (Padmalatha \& Prasad, } \\
\text { 2008) }\end{array}$ \\
\hline 1.6 & $\begin{array}{l}\text { Nine regenerated plants } \\
\text { (Lucknow, India) }\end{array}$ & $\begin{array}{l}\text { Out of } 40 \text { primers, } 19 \\
\text { RAPD were selected }\end{array}$ & $\begin{array}{l}\text { Average } 3.15 \text { bands per primer as average; } \\
\text { C. asiatica auxiliary buds/nodal encapsulates } \\
\text { efficiently stored up to } 200 \text { days; Confirmed genetic stability } \\
\text { of the regenerated plants form artificial synthetic seed }\end{array}$ & $\begin{array}{l}\text { (Archana Prasad et al., } \\
\text { 2014) }\end{array}$ \\
\hline 1.7 & $\begin{array}{l}13 \text { accessions of C.asiatica } \\
\text { (South India) } \\
\text { and Hydrocotyle }\end{array}$ & $\begin{array}{l}15 \text { RAPD markers out } \\
\text { of } 25\end{array}$ & $\begin{array}{l}\text { Mean Nei gene diversity } 0.2627,99.18 \% \text { polymorphism; } \\
\text { Cluster analysis produced single cluster with four sub clusters } \\
\text { for Centella asiatica; Cluster analysis differentiated Centella } \\
\text { asiatica from Hydrocotyle }\end{array}$ & (Thomas, 2010) \\
\hline 2. AFLP & $\begin{array}{l}4 \text { accessions (Bhowali (A), } \\
\text { Darjeeling (B), Bangalore } \\
(\mathrm{M}) \text {, Assam (E), India) }\end{array}$ & $\begin{array}{l}23 \text { primers } \\
\text { combinations }\end{array}$ & $\begin{array}{l}80.9 \% \text { polymorphism, } 0.04-0.38 \text { Jaccard similarity } \\
\text { coefficient; The accessions } \mathrm{M}\left(7.38 \mathrm{~g} \text { centellosides } / \mathrm{m}^{2}\right) \text { and A } \\
\left.\text { (total centellosides yield per unit area } 5.25 \mathrm{~g} / \mathrm{m}^{2}\right) \text { suggested } \\
\text { for commercial cultivation under agro climatic conditions of } \\
\text { the northern Indian plains }\end{array}$ & (A Prasad et al., 2014) \\
\hline $\begin{array}{l}\text { 3.EST-SSR } \\
\text { and RAPD } \\
3.1\end{array}$ & $\begin{array}{l}10 \text { plants species include } \mathrm{C} \text {. } \\
\text { asiatica (Bangalore, India) }\end{array}$ & $\begin{array}{l}10 \text { EST-SSR; } \\
4 \text { RAPD primer }\end{array}$ & $\begin{array}{l}\text { UPGMA (RAPD) cluster analysis separated } C \text {. asiatica as one ( } \\
\text { cluster and phylogenetic anlysis (SSR) clustered C. asiatica } \\
\text { with Anethum graveolens, Coriandrum sativum species; } \\
\text { Markers suggested as capable of transferring to closely } \\
\text { related species belonging to Apiaceae and Brassicaceae. }\end{array}$ & (Neelima, 2017) \\
\hline $\begin{array}{l}\text { 4.ISSR } \\
4.1\end{array}$ & $\begin{array}{l}162 \text { individuals } \\
\text { (14 populations) (China) }\end{array}$ & $\begin{array}{l}\text { Out of } 100 \text { ISSR, } 10 \\
\text { selected for analysis }\end{array}$ & $\begin{array}{l}\text { Average } 9.8 \text { bands per primer; Species level (Nei genetic } \\
\text { diversity }(\mathrm{H})=0.2183 \text {, percentage of polymorphic loci }(\mathrm{P})= \\
66.33 \% \text { ), and population level }(\mathrm{H} \text { ranged from } 0.021-0.1610, \\
\mathrm{P}=5.1-43.88 \%) \text {, Low gene flow }=0.2607 ; \text { Suggested } \\
\text { conservation of high genetic diversity population viz. Jinhua, } \\
\text { Fuzhou and Jiujiang populations for good agricultural practices. }\end{array}$ & $\begin{array}{l}\text { (X. G. Zhang et al., } \\
\text { 2012) }\end{array}$ \\
\hline 4.2 & $\begin{array}{l}\text { C. asiatica and Hydrocotyle } \\
\text { verticillata (Indonesia) }\end{array}$ & 30 ISSR & $\begin{array}{l}78 \% \text { polymorphism; Four markers potentially distinguish } H \text {. } \\
\text { verticillata and C. asiatica. }\end{array}$ & (Subositi et al., 2016) \\
\hline 4.3 & $\begin{array}{l}40 \text { individuals ( from } 3 \\
\text { Species) (Australia) }\end{array}$ & $\begin{array}{l}\text { Out of } 34 \text { primers, } \\
14 \text { were selected for } \\
\text { analysis }\end{array}$ & $\begin{array}{l}87.8 \% \text { polymorphism, } 0.47-1.00 \text { (Nei's similarity coefficient), } \\
\text { C. asiatica and C. cordifolia were clustered at similarity of } 0.61 \\
\text { and were hereditarily closer, but divergent from C. erecta }\end{array}$ & (Alqahtani et al., 2017) \\
\hline $\begin{array}{l}\text { 5.Genomic } \\
\text { SSR } \\
5.1\end{array}$ & $\begin{array}{l}17 \text { Accessions } \\
\text { (16 Madagascar, South } \\
\text { Africa and I India) }\end{array}$ & $\begin{array}{l}\text { Out of } 30 \text { SSR, } 20 \\
\text { were selected for } \\
\text { analysis }\end{array}$ & $\begin{array}{l}\text { Average } 4.3 \text { bands per primer, mean observed heterozygosity } \\
0.114 \text {, mean expected heterozygosity } 0.379 \text {; Genomic } \\
\text { microsatellites markers developed and characterized. }\end{array}$ & $\begin{array}{l}\text { (Rakotondralambo } \\
\text { et al., 2012) }\end{array}$ \\
\hline 5.2 & $\begin{array}{l}32 \text { accessions (Madagascar, } \\
\text { India, South Africa) }\end{array}$ & $\begin{array}{l}12 \text { SSR; } \\
5 \text { pairs of universal } \\
\text { chloroplastic primers }\end{array}$ & $\begin{array}{l}2.09 \text { (Diploid) and } 9.5 \text { (Tetraploid) alleles per locus, expected ( } \\
\text { heterozygosity (Diploid) =0.133-0.668; } 0 . \text { c52 Mean PIC } \\
\text { value; SSR analysis distinct genotypes Indian and South } \\
\text { African. Two chlorotypes (diploid and tetraploid populations) } \\
\text { disclosed by chloroplast analysis. }\end{array}$ & $\begin{array}{l}\text { (Rakotondralambo } \\
\text { et al., 2013) }\end{array}$ \\
\hline
\end{tabular}

5.3 $\quad 17$ genotypes including 20 Genomic SSR

Average 3.1 alleles per locus, $92.96 \%$ polymorphism,

(Rohini MR, Anuradha varieties (India) expected heterozygosity 0.456 , PIC 0.390 ; DNA barcode for Sane, Ravish Chaudhary, 17 genotypes developed using 10 SSR

2019) 
Table 1: (Continued)

\begin{tabular}{|c|c|c|c|c|}
\hline $\begin{array}{l}\text { Type of } \\
\text { Marker }\end{array}$ & $\begin{array}{l}\text { Samples/ } \\
\text { Accessions/ } \\
\text { Populations (Location) }\end{array}$ & Number of Primers & $\begin{array}{l}\text { Genetic parameters or indices and } \\
\text { Comments }\end{array}$ & References \\
\hline $\begin{array}{l}\text { 6.EST-SSR } \\
6.1\end{array}$ & $\begin{array}{l}10 \text { local cultivars (Apiaceae } \\
\text { family include C. asiatica) } \\
\text { Assam, India }\end{array}$ & $\begin{array}{l}\text { Out of } 18 \text { primers, } \\
6 \text { were amplified } \\
\text { effectively }\end{array}$ & \multirow{2}{*}{\multicolumn{2}{|c|}{$\begin{array}{l}\text { Average } 3 \text { alleles per primer, average } 0.95 \text { PIC value; Insilico (Sahu et al., 2015) } \\
\text { based EST-SSR markers were developed; Centella javanica } \\
\text { showed highest transferability of } 83.3 \% \text { with Centella } \\
\text { asiatica. } \\
\text { Average } 1.2 \text { alleles per primer, average PIC value 0.0195; } \quad \text { (Sakthipriya et al. } \\
\text { The molecular screening through microsatellite markers } \\
\text { showed low polymorphism }\end{array}$}} \\
\hline 6.2 & $\begin{array}{l}30 \text { Accessions (Tamil Nadu, } \\
\text { Kerala, India) }\end{array}$ & 10 EST-SSR & & \\
\hline
\end{tabular}

Standardizing the RAPD PCR condition for diversity study is important which was completed using 21 ecotypes by 8 primers in Nepal (Devkota, 2011; Devkota et al., 2011). Krishnan et al. studied the variation among the ten ecotypes using 4 decamers in south India (Krishnan et al., 2007). Likewise, C. asiatica was analyzed using the RAPD primers which showed differences in banding pattern from other plant species in China (Ruan et al., 2008). Perhaps due to cross-pollination, $87 \%$ polymorphism was observed between nine accessions collected from Andra Pradesh state, India using 16 primers (Padmalatha \& Prasad, 2008). These studies confirm the genetic variation found in the different ecotypes and also provide the marker information to differentiate genuine C. asiatica from its unauthenticated samples.

In other studies using RAPD primers were used to analyse 18 medicinal plants species including C. asiatica (Chikkaswamy, 2015; Paramanik \& Chikkaswamy, 2014; Radhika et al., 2012). Another researcher used a combination of marker systems namely AFLPs and Long Primer Randomly Amplified Polymorphic DNA (LP-RAPDs), to study genetic relationships among 12 accessions of $C$. asiatica which were collected from various regions of Peninsular Malaysia. The study identified an accession (CA03) with a different phenotype and shows a unique DNA profile when amplifying with AFLP and LPRAPD analyses. The lowest percentage of polymorphism was obtained as $8.15 \%$ (AFLPs) and $6.18 \%$ (LP-RAPDs) in CA05 (Mun, 2003). Thirteen accessions of C. asiatica from Southern India along with Hydrocotyl species was used to obtain genetic variability through 15 RAPD markers produced four sub-clusters for a single C. asiatica cluster in cluster analysis and differentiated Hydrocotyl species from C. asiatica (Thomas, 2010).

Another group confirmed the genetic stability of the regenerated plants from artificial synthetic seeds using RAPD (Archana Prasad et al., 2014). In another study, SSR and RAPD primers were used to access a diversity of C. asiatica. Authors suggested that the markers used in the study were capable of transferring to closely related species belonging to Apiaceae and Brassicaceae (Neelima, 2017). Reproducible 23 AFLP primers were used to screen germplasm of C. asiatica which yielded a sum of 696 fragments within this $563(80.9 \%)$ were found to be polymorphic. Accession $\mathrm{M}$ has shown genetic divergence from the other A, B, E accessions. They identified the accessions $\mathrm{M}$ and $\mathrm{A}$ for commercial cultivation (A Prasad et al., 2014).

\section{Inter Simple Sequence Repeats (ISSR)}

This highly polymorphic PCR based marker, dominant in nature, is distributed all over the genome and is widely used in genetic mapping, genetic diversity and evolutionary biology studies. It has advanced over other PCR markers like AFLP and RAPD (P. Kumar et al., 2009; Y. Zhang et al., 2016; Zietkiewicz et al., 1994). Fourteen C. asiatica populations from China comprising 162 individuals were used to estimate genetic diversity by ISSR primers. Out of 100 ISSR primers screened, 10 primers produced 98 clear and reproducible fragments. A high level of genetic diversity was obtained at the species level (Shannon's diversity index $(\mathrm{I})=0.3305$, Nei genetic diversity $(\mathrm{H})=0.2183$, percentage of polymorphic loci $(\mathrm{P})=66.33 \%$ ) and population level ( $\mathrm{H}$ ranged from $0.021-0.1610, \mathrm{P}=5.1-43.88 \%$, I = $0.031-0.2376)$ respectively. But the gene flow obtained was low $(\mathrm{Nm}=0.2607)$. This may be due to, geographical distance barriers that restrict gene flow that lead to such patterns of genetic structure and also some populations such as WC, HS, GZ, GA, WZ, JLP, and EM shown low Shannon's information index (X. G. Zhang et al., 2012).

Dyah Subositi and his research team analyzed C. asiatica and Hydrocotyle verticillata diversity via the ISSR marker system. Four markers had shown the potential to distinguish $H$. verticillata and C. asiatica. The (GA) ${ }_{8} \mathrm{CTT}$ and $(\mathrm{CT}){ }_{8} \mathrm{G}$ markers generated specific fragments for $C$. asiatica and one specific fragment of Hydrocotyle verticillata produced using $(\mathrm{GT})_{6} \mathrm{CC}$ and $(\mathrm{AG})_{8} \mathrm{~T}$ markers. This study shows the significance of the ISSR marker as a potential system to differentiate closely allied species (Subositi et al., 2016). Another study used three species of Centella viz. C. asiatica, C. cordifolia and C. erecta from Australia. 14 informative ISSR primers were used to estimate the genetic similarities among samples. The analyzed populations were grouped into three clusters in dendrogram based on Nei's genetic distance. C. asiatica and C. cordifolia were firstly clustered at a similarity of 0.61 and it shows that C. asiatica and C. cordifolia were hereditarily closer but divergent from $C$. erecta (0.47) (Alqahtani et al., 2017).

\section{Microsatellites or Simple Sequence Repeats (SSR)}

Microsatellite markers have various uses in the genetic studies of linkage in families, ecological research and linkage disequilibrium studies of populations (Al-Samarai \& Al-Kazaz, 2015; Litt \& Luty, 1989). In eastern Madagascar C. asiatica GA/GT-enriched a genomic library was constructed. Out of 30 SSR markers designed 
from this library, twenty were tested for polymorphism among 17 accessions of C. asiatica (16 from Madagascar and one from India). In this study, seventeen SSRs were found polymorphic and a total of 73 alleles with an average of 4.3 alleles per locus were obtained (Rakotondralambo et al., 2012). In another study, the genetic diversity analysis was performed in 30 accessions of C. asiatica using 10 EST SSR markers. The molecular screening through microsatellite markers showed low polymorphism (0.019) between the samples analyzed (Sakthipriya et al., 2018). Sahu et al., used local cultivars of 10 accessions from a different genus of the Apiaceae family to the check effectiveness of the selected 18 primers out of 603 EST-SSR primers designed. Only six primer pairs were amplified at 7 different loci in C. asiatica (average PIC value of 0.95 ) and further, these markers were tested for cross-transferability in nine other important genera/ species of the Apiaceae family. The PCR amplification revealed that all the six markers studied were cross-transferable at least in one of these genera and all the primers were polymorphic. In Centella javanica highest transferability of $83.3 \%$ was observed (Sahu et al., 2015).

Genetic diversity was analyzed in six wild C. asiatica populations collected from Madagascar and two other countries accessions using CpDNA and SSRs. Twelve SSR markers and 5 CpDNA primers were used to analyze the genome among the 32 accessions. In the case of SSR, the allelic number varied from 1-4 per population which may be due to whole-genome duplication. Indian accession was included in this study showed more than two alleles. The SSR analysis confirmed the divergence of leaf morphology of Malagasy C. asiatica within a sample collected from a single site due to active sexual reproduction (Rakotondralambo et al., 2013). Another research group analyzed seventeen genotypes of C. asiatica from India studied using 20 genomic SSR showed a low level of genetic diversity with an average similarity coefficient $(0.85)$ among them. Accessions IHRCA-5 and IHRCA-6 were found as the most distinct and the DNA barcode of 17 genotypes was developed (Rohini et al., 2019). Several studies using different ecotypes and different marker systems produced varying range of diversity values in C. asiatica, but marker selection for the practical application was not yet applied widely since markers within species linked to quantitative characters are seldom investigated.

\section{GENES CLONED AND CHARACTERIZED IN C. ASIATICA}

HMGR is the first and rate-limiting enzyme of the MVA pathway (mevalonate pathway) and might play important role in triterpenoid biosynthesis. Molecular cloning, characterization and expression analysis of 3-hydroxy-3-methylglutaryl-coenzyme A reductase gene (CaHMGR) was completed in C. asiatica and the 3D homology model generated showed $84.9 \%$ quality and its expression was higher in nodal region tissues followed by leaves, stem and root. The blast results of CaHMGR protein with genus Panax produced a high similarity value. Reports suggest that tissues in the nodal region might have an important role in terpenoid biosynthesis. Proteomic and SNP analysis of
Farnesyl diphosphate synthase from C. asiatica was also reported (Jawahar, 2017; Kalita et al., 2015).

Apart from this gene, many other genes are involved in the terpenoid biosynthesis pathway for C. asiatica were cloned. Phytosterols play a role in membrane constituents, and as precursors for hormone biosynthesis in higher plants. Cycloartenol synthase is an intermediate in phytosterol biosynthesis. Kim and his team isolated the cDNA of oxidosqualene cyclase, which encodes cycloartenol synthase and also full-length cDNA of CabAS (C. asiatica putative $\beta$-amyrin synthase) was cloned and sequenced. Its expression in leaves was confirmed by northern blot analysis. But it was suggested to rename as dammarenediol (CaDDS) after inducing the CabAS gene. In the terpenoid pathway, two molecules of farnesyl diphosphate (FPS) are converted into squalene by squalene synthase $(\mathrm{SQS})$, which is a common precursor of triterpenoid and sterol biosynthesis. Full-length cDNA clone of FPS and cDNA Squalene Synthase (CaSQS) was isolated and their sequence contains an open reading frame of 1029 nucleotides encoding 343 amino acids with a molecular mass of $39.6 \mathrm{kDa}$ and 1248 nucleotides, which code for 416 amino acids with a molecular mass of $47.3 \mathrm{kDa}$ respectively. A full-length cDNA clone encoding the glucosyltransferase for which the corresponding gene product was characterized using proteomic methods and cDNA sequence data. The transcriptome data of methyl jasmonate elicited C. asiatica leaves was used to identify the glycosyl transferase involved in asiaticoside formation. Four UGT candidate genes were selected and characterized by heterologous expression and found UGT3AHl protein catalyzes the glycosylation of ursane-type triterpene and produce asiatic acid monohexoside (Costa et al., 2017; Kim et al., 2005a, 2005b; Kim et al., 2017, 2009; Kim et al., 2005b, 2005a; Mangas et al., 2009).

\section{SEQUENCING BASED MARKERS USED IN C. ASIATICA}

Sequence-based markers and next-generation sequencing (NGS) are useful to study the genetic system and simultaneous sequencing for hundreds of thousands of molecules produce large volumes of sequence data. Plant genome sequencing development started when the first genome (Arabidopsis thaliana) was completed in 2000. The whole-genome short gun assembly of C. asiatica has a size of about $430.217 \mathrm{Mb}$ and it contains nine chromosome sequence information which was performed by National Center for Genetic Engineering and Biotechnology (BIOTEC), Thailand (Pootakham et al., 2021). Medicinal Materials DNA Barcode Database (MMDBD; https://rdccm.cuhk.edu.hk/mherbsdb/) and NCBI GenBank have the DNA sequence information of C. asiatica submitted which include regions of ITS, matK, rbcL, rpsl6, trnD-trnT, trnH-psbA, trnG, trnK-rps16, trnL, ycf5 and genome short gun assembly. ITS 2 DNA Barcode was sequenced and identified as a valuable marker for differentiating the C. asiatica from its adulterants (Xiao-chen Chen et al., 2012; Sarwat \& Yamdagni, 2016). The NCBI Sequence Read Archive (SRA) (https://www. ncbi.nlm.nih.gov/sra) contains 19 biosamples of C. asiatica as 
of $9^{\text {th }}$ March 2021 that include RNA sequence of leaf, stem, root tissues of C. asiatica (9 submissions), miRNA sequence of C. asiatica leaf (4 submissions), 454 sequencing of C. asiatica elicited by methyl jasmonate (1 submission), transcriptome sequence of C. asiatica (1), transcriptome analysis of root (3 submissions) and leaf (1 submission).

Sangwan et al., conducted a broad analysis of C. asiatica leaf transcriptome sequence assembly and gene ontology prediction analyses. By Illumina (Solexa sequencing technology), paired sequencing of the three RNA pooled samples leaf transcriptome of C. asiatica produced 7.07 GB of sequence data in fastq format with over 41,922 important identities of transcripts. This study produced good coverage of the transcriptome and was useful to find out major pathway genes. 71 different transcription factor types have been found in the transcripts. Zinc finger family transcription factor class was found in large numbers (424) followed by F-Box Homeobox, myb WD40 repeat family, BHLH, AP2, GRAS, GATA etc. Seventeen gene sequences involved in the secondary metabolic pathways were identified. The real-time PCR (qRT-PCR) analysis was conducted in stem, leaf, seed and root tissues of the plant to confirm the bioinformatics practices. From this, leaf tissue was shown a higher level of expression of all the secondary metabolite genes than other plant tissues investigated. This study represents the major report on C. asiatica transcriptome based gene resource development (Sangwan et al., 2013).

A small molecule of endogenous RNA (21-24 nucleotide) called miRNA could be used as a marker for the identification of gene of interest as well as helpful in the breeding approach. miRNA plays a role in biological processes and posttranscriptional regulation (Xuemei Chen, 2005; Gangadhar et al., 2014). miRNA based marker is evolving as a new marker of choice because of its highly conserved nature. miRNA based markers already developed for genotyping various plants including medicinal plants viz Moringa oleifera (Pirro et al., 2016), Silyum marianum (Ražná et al., 2015) etc. PMRD (plant microRNA database) (Z. Zhang et al., 2010), miRNEST (Szcześniak et al., 2012), mPC (MicroPC) (Mhuantong \& Wichadakul, 2009) and miRBase (Griffiths-Jones et al., 2007) are some of the miRNA databases which include published miRNA sequences and annotations (B. Zhang \& Wang, 2015). C. asiatica miRNA sequences were submitted to the NCBI SRA database from JNTBGRI. miRNA primers (miR477e, miR156d, miRl69f, miR397 and miR172) which are indicative of plant stress were used for Real-Time RT-PCR in in vitro grown C. asiatica samples. An initial downregulation was observed in miRl69f and miRl72 and overexpression in miR477e, miR156d and miR397 from 30 to 45 days cultures. This upregulation of miR156, miRl72 and miR397 in C. asiatica could be due to the correlation with the enhancement in biomass, levels of auxins/cytokinins and tolerance to cold stress respectively (Jisha et al., 2019). Another source for molecular marker development, the Chloroplast genome of C. asiatica was sequenced by Chan Li et al. The sequenced Chloroplast genome contains $62.30 \%$ of AT content and 113 genes (4 rRNA genes, 79 protein-coding genes, 30 tRNA genes) (C. Li et al., 2020).

\section{CHROMOSOME AND POLYPLOIDY STUDY}

C. asiatica karyotype was studied in ten ecotypes (Das \& Mallick, 1991). The chromosomal variation was found in secondary constriction, total chromosome length and volume, total F\% value which might be due to duplication and translocation that occurred in the chromosome during an early stage of evolution. Apart from the normal chromosome $2 \mathrm{n}=18$, some ecotypes shown additional B chromosome and also a reduction in the size of autosomes. Tetraploid was first reported in C. asiatica $(2 \mathrm{n}=36)$ by Kokubugatai et al (Kokubugata et al., 1998). Polyploid breeding was tested in C. asiatica, in which a saturated paradichlorobenzene (pDB) antimitotic agent effectively induced the autotetraploid. The induced plant produced a higher amount of asiaticoside and increased plant size. Genetically stable mixoploid with higher phytomass and triterpenoid content was produced by colchicine $0.025-0.1 \%$ concentration for 12-24 hr induction in C. asiatica (Dalave \& Apparao, 2007; Kaensaksiri et al., 2010). The study conducted by Rakotondralamo et al. (2013) confirmed the presence of tetraploidy of C. asiatica population with 36 chromosomes and diploid population which shown evidence for polyploidy complex nature.

\section{CONSERVATION AND CULTIVATION}

Biodiversity nowadays is changing in an uncontrolled way, the most cause of these changes are due to changes in climate, pollution, unsustainable harvesting of natural resources, increase in the human population followed by an increase in consumption rate. Due to these kinds of disturbances, great numbers of plant resources are lost forever. Conservation involves the preservation of available genetic diversity. Many researchers believe that medicinal plants collected from wild habitats than cultivated have more active secondary metabolite content. But continuous use of wild resources will lose the genetic diversity in that habitat so conservation plays a role to preserve this. Around the world, many conservation programmes are initiated widely.

In India, for the collection and conservation of medicinal plants, many institutes are involved under Government schemes. Those institutes include institutes working under AYUSH, state forest departments under the Ministry of Environment and Forests (minor forest products), CSIR under the Department of Science and Technology, Defence Research and Development Organization and apart from these agriculture universities, the Department of Biotechnology, CSIR-Central Institute of Medicinal and Aromatic Plants (CIMAP), Directorate of Medicinal and Aromatic Plants Research (DMAPR), Central Council for Research in Ayurveda and Siddha under Ministry of Health and Family Welfare, National Bureau of Plant Genetic Resources (NBPGR), New Delhi, Ministry of Agriculture, Farmers Welfare under the support of Indian Council of Agriculture Research (ICAR), G-15 project funded by Department of Biotechnology, three medium-term conservation facilities were created in India, viz. CIMAP in Lucknow, JNTBGRI in Thiruvananthapuram and NBPGR in New Delhi 
for the conservation (Bandara et al., 2011; Bhau, 2012; Devkota \& Jha, 2010; V. Gupta, 2018; A. Kumar \& Jnanesha, 2017; Lal et al., 2017; Mathur et al., 2000; NMPB, 2014; Patel, 2015; Rao, 2016; Tandon et al., 2009; Vinolina et al., 2012). Several State/Central Government funded projects involving diverse medicinal plants conservation have been completed or are being carried out such as JNTBGRI has developed ex-situ conservation of the genetic resource of selected medicinal plants, constructed field Gene Banks and seed bank and practice assessment of intraspecific genetic variability using molecular markers; CSIRCentral Institute of Medicinal and Aromatic Plants Research Centre (CIMAP), Hyderabad, India, selected medicinal plants of the Deccan plateau region and maintained them in a field gene bank and seed bank. Many medicinal plants including C. asiatica are rich in the Western (3500 species) and Eastern (>1500 species) Ghats (JNTBGRI, 2016; NMPB, 2014).

For the cultivation of C. asiatica, the nodular part of the stem/ runner clonal propagation was suggested. This method was acceptable and succeeded when they are grown under favorable conditions but this herb is still considered a wild plant and has not undergone domestication widely. In the case of seed germination is at a warm environment $\left(25-30^{\circ} \mathrm{C}\right), \mathrm{C}$. asiatica germination percentage in two to three months of old seed was recorded as $82 \%$ than the fresh seed. Released varieties of C. asiatica by CSIR-CIMAP called CIM Medha, RK-2, CA-7 and CA-4 were suggested for commercial cultivation. Majja Poshak, Subhodak, RK1, RK2 are also developed as cultivable varieties. Fresh herbage yield $(12,331 \mathrm{~kg} / \mathrm{ha})$ and dry herbage yield $(2,113 \mathrm{~kg} / \mathrm{ha})$ of high-yielding cultivar Vallabh Medha of mandukparni variety was identified by ICAR, India and also released Arka Prabhavi (CA-13) documented higher Asiaticoside content (>3\%) (ICAR, 2021b), Arka Divya (CA1) with broadleaf, mineral and vitamin A $(32.33 \mathrm{mg} / 100 \mathrm{~g})$ (ICAR, 202la). Gotu kola cultivation through an aquaponic facility was exhibited at Crop Diversification Center South (CDCS), Canada which shows chlorosis in early stages, but it recovered subsequently. A study conducted on co-cultivation of C. asiatica with Piriformospora indica in pot experiments produced improvement in growth promotion and stress tolerance; this gives a good sign for a new way of cultivation. C. asiatica of 16 accessions collected from India screened for the ideal condition for growth. They identified CaBp and $\mathrm{CaCl}$ accessions produced high herbage and asiaticoside yields under full light and shading conditions; CaShT was recognized for its very high herbage and asiaticoside. National Medicinal Plants Board, India recommended that for the propagation and cultivation of C. asiatica, $300 \mathrm{~kg}$ rooted suckers are needed to plant one hectare of land and the maturity period is around 90 days to harvest. The harvest obtained in a year is $10-12$ t/ha yield which is obtained by 3 harvests. For the cost of cultivation for one hectare Rs. 40000/- may be required (Jisha et al., 2019; NMPB, 2014; Satheesan \& Sabu, 2019).

\section{BIOLOGICAL DATABASES}

Biological databases would be the most preferred choice to gather available genetic information. Many databases are helpful to provide data on medicinal plants. Notable databases include the National Center for Biotechnology Information (NCBI) GenBank (http://www.ncbi.nlm.nih.gov/genbank/), International Nucleotide Sequence Database Collaboration (INSDC; http://www.insdc.org), PIR (Protein Information Resource; https://proteininformationresource.org/), PDB (Protein Data Bank) (http://www.rcsb.org/pdb/home/home. do), DNA Data Bank of Japan (DDBJ; http://www.ddbj.nig. ac.jp/), KEGG (Kyoto Encyclopedia of Genes and Genomes) (https://www.genome.jp/kegg/), MMDB (Molecular Modeling Database) (http:/www.ncbi.nlm.nih.gov/Structure/MMDB/ mmdb.shtml), European Molecular Biology Laboratory's European Bioinformatics Institute (EMBL-EBI; http://www.ebi. ac.uk/embl/), UniProtKB/Swiss-Prot (http://www.uniprot.org/ uniprot) and Entrez Protein Database (https://www.ncbi.nlm. nih.gov/protein) (Amid et al., 2012; Barker et al., 1998; Benson et al., 2000; Berman et al., 2002; Boutet et al., 2016; J. Chen et al., 2003; Kaminuma et al., 2010; Kanehisa \& Goto, 2000; S. Kumar \& Shanker, 2018; Wheeler et al., 2007).

Some of the web resources available are helpful to gather the knowledge of medicinal plants such as Indian Medicinal Plants Database (http://www.medicinalplants.in/aboutfrlhtdb), The HerbMed (http://www.herbmed.org), The Indian Medicinal Plants, Phytochemistry, and Therapeutics (IMPPAT; https:// cb.imsc.res.in/imppat/home), Medicinal Materials DNA Barcode Database (MMDBD; http://www.cuhk.edu.hk/icm/mmdbd.htm), Natural Products Alert (NAPRALERT; https://www.napralert.org/ about), Indonesian medicinal plants database (http://herbaldb. farmasi.ui.ac.id), The Natural Medicines Comprehensive Database (http://www.naturaldatabase.com), Natural Products CARE (NPCARE; http://silver.sejong.ac.kr/npcare) and Super Natural II (http://bioinfapplied.charite.de/supernatural_new/ index.php) (Banerjee et al., 2015; Choi et al., 2017; Hsu, 2002; S. Kumar \& Shanker, 2018; Lou et al., 2010; Loub et al., 1985; Mohanraj et al., 2018; Wootton, 2002; Yanuar et al., 2011)

\section{CONCLUSION REMARKS}

C. asiatica has been recognized as an imperative drug in various Pharmacopoeia of the world viz. India, Germany, Europe and the People's Republic of China. Even though it was a highly demanded and traded plant according to Indian Medicinal Plants Database, the source for trading mainly from the wild, so ultimately it would lead to overexploitation and hence cultivation and breeding strategies are to be developed to improve the availability. Molecular marker-assisted breeding is popular in crop plants but in medicinal plants only a few reports are available. DNA markers would be helpful in markerassisted breeding and validating the medicinal plant specimens required for making pharmaceutical products (Azizi, 2010; Choudhri et al., 2018; Dong et al., 2017; Prakash et al., 2017; Sharma et al., 2018; Zeng et al., 2010). WHO suggests correct identification and quality assurance required for traditional medicine. Molecular markers can be used for such testing and biological standardization. Utilization of genetic markers for studying physiology, genetics, taxonomy etc are common among food crops and horticultural plants but lately, they are 
being used in pharmacognostic characterization to locate the gene, to improve as well as to authenticate the plant varieties, genome analysis, genetic characterization, fingerprinting, understating the heritability and phylogenetic analysis to predict evolutionary theories in medicinal plants. Gene microarray study in C. asiatica helped to understand the bioactivity and molecular mechanism (Belwal et al., 2019; Chavan et al., 2006; Coldren et al., 2003; Srivastava et al., 2009; Tan, 2017). Various genetic analyses implementation would be helpful in betterquality accessions selection and new cultivar development in C. asiatica. This review shows the requisite research path on its genetic research gap and also provides awareness on the requirement for its improvement in conservation, cultivation and genetic improvement of this medicinal plant.

\section{ACKNOWLEDGEMENTS}

Authors thank the Director, JNTBGRI for providing the necessary facilities. MS acknowledges the receipt of PhD fellowship (IF150469) through INSPIRE scheme of the Department of Science and Technology, Government of India. MS thank Mr Shefeek for helping in taking a photo of C. asiatica (Figure 1).

\section{CONFLICT OF INTEREST}

It is authors declared that no conflict of interest in the publication of this article.

\section{REFERENCES}

Agarwal, M., Shrivastava, N., \& Padh, H. (2008). Advances in molecular marker techniques and their applications in plant sciences. Plant Cell Reports, 27(4), 617-631. https://doi.org/10.1007/s00299-008-0507-z

Al-Samarai, F. R., \& Al-Kazaz, A. A. (2015). Molecular Markers: an Introduction and Applications. European Journal of Molecular Biotechnology, 9(3), 118-130. https://doi.org/10.13187/ejmb.2015.9.118

Alqahtani, A., Cho, J., Wong, K. H., \& Li, K. M. (2017). Differentiation of Three Centella Species in Australia as Inferred from Morphological Characteristics, ISSR Molecular Fingerprinting and Phytochemical Composition. Frontiers in Plant Science, 8, 1980. https://doi. org/10.3389/fpls.2017.01980

Amid, C., Birney, E., Bower, L., Cerdeño-Tárraga, A., Cheng, Y., Cleland, I., Faruque, N., Gibson, R., Goodgame, N., Hunter, C., Jang, M., Leinonen, R., Liu, X., Oisel, A., Pakseresht, N., Plaister, S., Radhakrishnan, R., Reddy, K., Rivière, S., Rossello, M., Senf, A., Smirnov, D., Ten Hoopen, P., Vaughan, D., Vaughan, R., Zalunin, V., \& Cochrane, G. (2012). Major submissions tool developments at the European Nucleotide Archive. Nucleic Acids Research, 40(D1), D43-D47. https://doi.org/10.1093/nar/gkr946

Azizi, A. (2010). Genetic, chemical and agro-morphological evaluation of the medicinal plant Origanum vulgare L. for marker assisted improvement of pharmaceutical quality. Justus Liebig University Giessen, Institute of Crop Science and Plant breeding I, Giessen, Germany.

Bandara, M. S., Lee, E. L., \& Thomas, J. E. (2011). Gotu Kola (Centella asiatica L.): An Under-utilized Herb. The American Journal of Plant Science and Biotechnology, 5(2), 20-31.

Banerjee, P., Erehman, J., Gohlke, B.-O., Wilhelm, T., Preissner, R., \& Dunkel, M. (2015). Super Natural II—a database of natural products. Nucleic Acids Research, 43(D1), D935-D939. https://doi.org/10.1093/ nar/gku886

Barker, W. C., Garavelli, J. S., Haft, D. H., Hunt, L. T., Marzec, C. R., Orcutt, B. C., Srinivasarao, G. Y., Yeh, L.-S. L., Ledley, R. S., \& Mewes, H.-W. (1998). The PIR-international protein sequence database. Nucleic Acids Research, 26(1), 27-32.
Belwal, T., Andola, H. C., Atanassova, M. S., Joshi, B., Suyal, R., Thakur, S., Bisht, A., Jantwal, A., Bhatt, I. D., \& Rawal, R. S. (2019). Gotu Kola (Centella asiatica). In Nonvitamin and Nonmineral Nutritional Supplements (pp. 265-275). Elsevier. https://doi.org/10.1016/B9780-12-812491-8.00038-2

Benson, D. A., Karsch-Mizrachi, I., Lipman, D. J., Ostell, J., Rapp, B. A., \& Wheeler, D. L. (2000). GenBank. Nucleic Acids Research, 28(1), 15-18. https://doi.org/10.1093/nar/gkz956

Berman, H. M., Battistuz, T., Bhat, T. N., Bluhm, W. F., Bourne, P. E., Burkhardt, K., Feng, Z., Gilliland, G. L., Iype, L., \& Jain, S. (2002). The protein data bank. Acta crystallographica. Section D, Biological Crystallography, 58, 899-907. https://doi.org/10.1107/ s0907444902003451

Bhau, B. S. (2012). Molecular markers in the improvement of the medicinal plants. Medicinal Aromatic Plants, 1(2), 1-2.

Boutet, E., Lieberherr, D., Tognolli, M., Schneider, M., Bansal, P., Bridge, A. J., Poux, S., Bougueleret, L., \& Xenarios, I. (2016). UniProtKB/SwissProt, the manually annotated section of the UniProt KnowledgeBase: how to use the entry view. In Plant Bioinformatics (pp. 23-54) Springer.

Bylka, W., Znajdek-Awizeń, P., Studzińska-Sroka, E., \& Brzezińska, M. (2013). Centella asiatica in cosmetology. Postepy Dermatologii i Alergologii, 30(1), 46-49. https://doi.org/10.5114/pdia.2013.33378

CABI. (2020). Centella asiatica (Asiatic pennywort). Retrived from https:// www.cabi.org/isc/datasheet/12048\#227A4325-4F30-4423-A9168C5062CD67A1

Chavan, P., Joshi, K., \& Patwardhan, B. (2006). DNA microarrays in herbal drug research. Evidence-Based Complementary and Alternative Medicine, 3(4), 447-457. https://doi.org/10.1093/ecam/nel075

Chen, H., Semagn, K., Iqbal, M., Moakhar, N. P., Haile, T., N'Diaye, A., Yang, R. C., Hucl, P., Pozniak, C., \& Spaner, D. (2017). Genome-wide association mapping of genomic regions associated with phenotypic traits in Canadian western spring wheat. Molecular Breeding, 37(141), 1-18. https://doi.org/10.1007/s11032-017-0741-6

Chen, J., Anderson, J. B., DeWeese-Scott, C., Fedorova, N. D., Geer, L. Y., He, S., Hurwitz, D. I., Jackson, J. D., Jacobs, A. R., Lanczycki, C. J., Liebert, C. A., Liu, C., Madej, T., Marchler-Bauer, A., Marchler, G. H., Mazumder, R., Nikolskaya, A. N., Rao, B. S., Panchenko, A. R., Shoemaker, B. A., Simonyan, V., Song, J. S., Thiessen, P. A., Vasudevan, S., Wang, Y., Yamashita, R. A., Yin, J. J., \& Bryant, S. H. (2003). MMDB: Entrez's 3D-structure database. Nucleic Acids Research, 31(1), 474-477. https://doi.org/10.1093/nar/gkg086

Chen, Xiao-chen, Chen, Q., \& Han, J. (2012). Molecular Identification of Centella asiatica and Its Adulterants Using ITS2 DNA Barcode. Modern Chinese Medicine, 3.

Chen, X. (2005). MicroRNA biogenesis and function in plants. FEBS Letters, 579(26), 5923-5931. https://doi.org/10.1016/j.febslet.2005.07.071

Chikkaswamy, B. K. (2015). Assessment of genetic diversity and relationships of medicinal plants using RAPD marker. International Journal of Advanced Research in IT and Engineering, 4(2), 25-35.

Choi, H., Cho, S. Y., Pak, H. J., Kim, Y., Choi, J., Lee, Y. J., Gong, B. H., Kang, Y. S., Han, T., \& Choi, G. (2017). NPCARE: database of natural products and fractional extracts for cancer regulation. Journal of Cheminformatics, 9(1), 1-9. https://doi.org/10.1186/s13321-0160188-5

Choudhri, P., Rani, M., Sangwan, R. S., Kumar, R., Kumar, A., \& Chhokar, V. (2018). De novo sequencing, assembly and characterisation of Aloe vera transcriptome and analysis of expression profiles of genes related to saponin and anthraquinone metabolism. BMC Genomics, 19(1), 427. https://doi.org/10.1186/s12864-018-4819-2

Coldren, C. D., Hashim, P., Ali, J. M., Oh, S.-K., Sinskey, A. J., \& Rha, C. K. (2003). Gene expression changes in the human fibroblast induced by Centella asiatica triterpenoids. Planta Medica, 69(08), 725-732. https://doi.org/10.1055/s-2003-42791

Collard, B. C. Y., Jahufer, M. Z. Z., Brouwer, J. B., \& Pang, E. C. K. (2005). An introduction to markers, quantitative trait loci (QTL) mapping and marker-assisted selection for crop improvement: the basic concepts. Euphytica, 142(1-2), 169-196. https://doi.org/10.1007/ s10681-005-1681-5

Costa, A. F. De, Barber, C. J. S., Reed, D. W., Zhang, H., Fett-neto, A. G., \& Covello, P. S. (2017). Molecular cloning of an ester-forming triterpenoid: UDP-glucose 28-O-glucosyltransferase involved in saponin biosynthesis from the medicinal plant Centella asiatica. Plant Science, 262(9-17). https://doi.org/10.1016/j. plantsci.2017.05.009 
Dalave, S. C., \& Apparao, B. J. (2007). Genetic improvement of Centella asiatica L. for high yields of asiaticoside. Planta Medica, 73(09), P_620. https://doi.org/10.1055/s-2007-987400

Das, A., \& Mallick, R. (1991). Correlation between genomic diversity and asiaticoside content in. Botanical Bulletin of Academia Sinica, 32, 1-8.

Devkota, A. (2011). Ecophysiological study of Centella asiatica (Linn.) Urban of Nepal. Central Department of Botany Institute of Science and Technology, Tribhuvan.

Devkota, A., Bimb, H. P., Bajracharya, J., \& Jha, P. K. (2011). Optimization of RAPD-PCR conditions for the study of genetic diversity of Centella asiatica. Nepal Journal of Science and Technology, 12, 69-74. https:// doi.org/10.3126/njst.v12i0.6482

Devkota, A., \& Jha, P. K. (2010). Seed germination responses of the medicinal herb Centella asiatica. Brazilian Journal of Plant Physiology, 22(2), 143-150. https://doi.org/10.1590/S1677-04202010000200008

Dong, L. L., Chen, Z. J., Wang, Y., Wei, F. G., Zhang, L. J., Xu, J., Wei, G. F., Wang, R., Yang, J., Liu, W. L., Li, X. W., Yu, Y. Q., \& Chen, S. L. (2017). DNA marker-assisted selection of medicinal plants (I). Breeding research of disease-resistant cultivars of Panax notoginseng. Zhongguo Zhong Yao Za Zhi= Zhongguo Zhongyao Zazhi= China Journal of Chinese Materia Medica, 42(1), 56-62. https://doi. org/10.19540/j.cnki.cjcmm.2017.0004

Gangadhar, B. H., Jyoti, A., Srivastva, V., \& Mishra, R. K. (2014). Development of Insilico Based Molecular Marker Systems in Medicinal Plants of India : Future Prospects available among them $90 \%$ are belonging to forest habitats. //(1), 581-611.

Griffiths-Jones, S., Saini, H. K., van Dongen, S., \& Enright, A. J. (2007). miRBase: tools for microRNA genomics. Nucleic Acids Research, 36, D154-D158. https://doi.org/10.1093/nar/gkm952

Gupta, P. K., Varshney, R. K., Sharma, P. C., \& Ramesh, B. (1999). Molecular markers and their applications in wheat breeding. Plant Breeding, 118(5), 369-390. https://doi.org/10.1046/j.1439-0523.1999.00401.x

Gupta, V. (2018). Indian plant genetic resources of medicinal value. In New Age Herbals (pp. 267-287). Springer.

Hsu, P. P. (2002). Natural medicines comprehensive database. Journal of the Medical Library Association, 90(1), 114.

ICAR. (2021a). Arka Divya (CA-1). https://iihr.res.in/variety/arka-divya-ca-1

ICAR. (2021b). Arka Prabhavi (CA-13). https://iihr.res.in/variety/arkaprabhavi-ca-13

Jawahar, P. (2017). SNP Analysis of Farnesyl Diphosphate Synthase from Centella asiatica. Lulu Publication, United States.

Jisha, S., Anith, K. N., \& Sabu, K. K. (2019). The protective role of Piriformospora indica colonization in Centella asiatica (L.) in vitro under phosphate stress. Biocatalysis and Agricultural Biotechnology, 19, 101088. https://doi.org/10.1016/j.bcab.2019.101088

Jisha Satheesan, A.S. Hemanthkumar, Gouri priya Ranjith, K. K. S. (2019). Expression profiling of selected microRNAs coupled with molecular and biochemical analyses of asiaticosides in Centella asiatica (L.) Urb in vitro. International Journal of Pharmacy and Pharmaceutical Sciences, 11(5), 19-26. https://doi.org/10.22159/ ijpps.2019v11i5.32097

JNTBGRI. (2016). Annual Report of Jawaharlal Nehru Tropical Botanic Garden and Research Institute 2014-2016.

Joshi, S. P., Ranjekar, P. K., \& Gupta, V. S. (1999). Molecular markers in plant genome analysis. Current Science, 77(2), 230-240.

Kaensaksiri, T., Soontornchainaksaeng, P., Soonthornchareonnon, N., \& Prathanturarug, S. (2010). Mutational breeding of Centella asiatica (L.) urban for medicinal purposes. Planta Medica, 76(12), P182. https:// doi.org/10.1055/s-0030-1264480

Kalita, R., Patar, L., Kumar, A., \& Mahendra, S. (2015). Molecular cloning, characterization and expression analysis of 3-hydroxy-3methylglutaryl coenzyme A reductase gene from Centella asiatica L. Molecular Biology Reports, 42, 1431-1439. https://doi.org/10.1007/ s11033-015-3922-6

Kaminuma, E., Kosuge, T., Kodama, Y., Aono, H., Mashima, J., Gojobori, T., Sugawara, H., Ogasawara, O., Takagi, T., \& Okubo, K. (2010). DDBJ progress report. Nucleic Acids Research, 39, D22-D27. https://doi. org/10.1093/nar/gkq1041

Kanehisa, M., \& Goto, S. (2000). KEGG: kyoto encyclopedia of genes and genomes. Nucleic Acids Research, 28(1), 27-30. https://doi. org/10.1093/nar/28.1.27

Kim, O.-T., Kim, M.-Y., Hwang, S.-J., Ahn, J.-C., \& Hwang, B. (2005). Cloning and molecular analysis of cDNA encoding cycloartenol synthase from Centella asiatica (L.) urban. Biotechnology and Bioprocess
Engineering, 10(1), 16. https://doi.org/10.1007/BF02931177

Kim, O.-T., Seong, N.-S., Kim, M.-Y., \& Hwang, B. (2005). Isolation and characterization of squalene synthase cDNA from Centella asiatica (L.) urban. Journal of Plant Biology, 48(3), 263. https://doi.org/10.1007/ BF03030521

Kim, O. T., Ahn, J. C., Hwang, S. J., \& Hwang, B. (2005). Cloning and expression of a farnesyl diphosphate synthase in Centella asiatica (L.) Urban. Molecules \& Cel/s, 19(2), 294-299.

Kim, O. T., Jin, M. L., Lee, D. Y., \& Jetter, R. (2017). Characterization of the asiatic acid glucosyltransferase, UGT73AH1, involved in asiaticoside biosynthesis in Centella asiatica (L.) Urban. International Journal of Molecular Sciences, 18(12), 2630.

Kim, O. T., Kim, M. Y., Huh, S. M., Bai, D. G., Ahn, J. C., \& Hwang, B. (2005). Cloning of a cDNA probably encoding oxidosqualene cyclase associated with asiaticoside biosynthesis from Centella asiatica (L.) Urban. Plant Cel/ Reports, 24(5), 304-311. https://doi.org/10.1007/ s00299-005-0927-y

Kim, O. T., Lee, J. W., Bang, K. H., Kim, Y. C., Hyun, D. Y., Cha, S. W., Choi, Y. E., Jin, M. L., \& Hwang, B. (2009). Characterization of a dammarenediol synthase in Centella asiatica (L.) Urban. Plant Physiology and Biochemistry, 47(11-12), 998-1002. https://doi. org/10.1016/j.plaphy.2009.08.001

Kokubugata, G., Kondo, K., \& Randall, L. M. (1998). Intraspecific polyploidy in Centella asiatica and their karyotypes in five populations in Australia and Japan. Chromosome Science, 2(1), 43-46.

Krishnan, G. R. P., Prasad, V., Rajmohan, K., \& Soni, K. B. (2007). RAPD Analysis of Centella asiatica Ecotypes. Recent Trends in Horticultural Biotechnology (Volume II), 593-597.

Kumar, A., \& Jnanesha, A. C. (2017). Genetic diversity and conservation of medicinal plants in Deccan plateau region in India. Journal of Medicinal Plants, 5(3), 27-30.

Kumar, P., Gupta, V. K., Misra, A. K., Modi, D. R., \& Pandey, B. K. (2009). Potential of molecular markers in plant biotechnology. Plant Omics, 2(4), 141.

Kumar, S., \& Shanker, A. (2018). Biological Databases for Medicinal Plant Research. In Biotechnological Approaches for Medicinal and Aromatic Plants (pp. 655-665). Springer.

Lal, R. K., Gupta, P., \& Dubey, B. K. (2017). Genetic variability and associations in the accessions of Manduk parni $\{$ Centella asiatica (L)\}. Industria/ Crops and Products, 96, 173-177. https://doi.org/10.1016/j. indcrop.2016.11.056

Li, C., Xie, X., Li, F., Tian, E., Shu, Y., \& Chao, Z. (2020). The complete chloroplast genome sequence of Centella asiatica (Linnaeus) Urban. Mitochondrial DNA Part B, 5(3), 2149-2150. https://doi.org/10.1080/ 23802359.2020.1768922

Litt, M., \& Luty, J. A. (1989). A hypervariable microsatellite revealed by in vitro amplification of a dinucleotide repeat within the cardiac muscle actin gene. American Journal of Human Genetics, 44(3), 397.

Lou, S.-K., Wong, K.-L., Li, M., But, P. P.-H., Tsui, S. K.-W., \& Shaw, P.-C. (2010). An integrated web medicinal materials DNA database: MMDBD (Medicinal Materials DNA Barcode Database). BMC Genomics, 11(1), 402.

Loub, W. D., Farnsworth, N. R., Soejarto, D. D., \& Quinn, M. L. (1985). NAPRALERT: computer handling of natural product research data. Journal of Chemical Information and Computer Sciences, 25(2), 99-103. https://doi.org/10.1021/ci00046a009

Mangas, S., Moyano, E., Hernandez-Vazquez, L., \& Bonfill, M. (2009). Centella asiatica (L) Urban: An updated approach. Plant Secondary Terpenoids, Research Signpost, 37(661), 55-74.

Mathur, S., Verma, R. K., Gupta, M. M., Ram, M., Sharma, S., \& Kumar, S (2000). Screening of genetic resources of the medicinal-vegetable plant Centella asiatica for herb and asiaticoside yields under shaded and full sunlight conditions. The Journal of Horticultura/ Science and Biotechnology, 75(5), 551-554. https://doi.org/10.1080/14620316.2 000.11511284

Mhuantong, W., \& Wichadakul, D. (2009). MicroPC ( $\mu$ PC): A comprehensive resource for predicting and comparing plant microRNAs. BMC Genomics, 10(1), 366. https://doi.org/10.1186/1471-2164-10-366

Mohanraj, K., Karthikeyan, B. S., Vivek-Ananth, R. P., Chand, R. P. B., Aparna, S. R., Mangalapandi, P., \& Samal, A. (2018). IMPPAT: A curated database of I ndian $M$ edicinal $P$ lants, $P$ hytochemistry $A$ nd $T$ herapeutics. Scientific Reports, 8(1), 1-17. https://doi.org/10.1038/ s41598-018-22631-z

Mun, W. S. (2003). Molecular genetic characterization of different 
accessions of Centella asiatica. Masters thesis. Universiti Putra, Malaysia.

National Medicinal Plants Board. (2015). Demand and Supply Position of Medicinal Plants. India. https://nmpb.nic.in/content/demand-andsupply-position-medicinal-plants

Neelima, M. G. (2017). Phylogenetic studies in apiaceae using RAPD and SSR markers. Journal of Cytology and Genetics, 18, 9-20.

NMPB. (2014). Agro-techniques of Selected Medicinal Plants Vollume II. National Medicinal Plants Board, Department of AYUSH, Ministry of Health and Family Welfare, Government of India, 2014. https:// www.nmpb.nic.in/sites/default/files/publications/Agro_techniques_ of selected_medicinal_plants_Vol-II.pdf

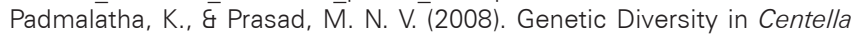 asiatica (L.) Urb., a Memory-Enhancing Neutraceutical Herb, using RAPD Markers. Medicinal and Aromatic Plant Science and Biotechnology, 2(2), 90-95.

Paramanik, R. C., \& Chikkaswamy, B. K. (2014). Study on Genetic Diversity relationship some Medicinal plantsusing RAPD Molecular marker. International Journal of Current. Microbiology and Applied Science, 6. 1004-1015.

Patel, D. K. (2015). Growth pattern study on Centella asiatica (L.) Urban in herbal garden. International Journal of Herbal Medicine, 3(5), 9-12.

Pirro, S., Zanella, L., Kenzo, M., Montesano, C., Minutolo, A., Potesta, M., Sobze, M. S., Canini, A., Cirilli, M., \& Muleo, R. (2016). MicroRNA from Moringa oleifera: identification by high throughput sequencing and their potential contribution to plant medicinal value. PLoS One, 11(3). https://doi.org/10.1371/journal.pone.0149495

Pootakham, W., Naktang, C., Kongkachana, W., Sonthirod, C., Yoocha, T., Sangsrakru, D., Jomchai, N., Sonicha, U., Romyanon, K., \& Toojinda, T. (2021). De novo chromosome-level assembly of Centella asiatica genome. Genomics, 113(4), 2221-2228. https://doi.org/10.1016/j. ygeno.2021.05.019

Prakash, V., Jaiswal, N., \& Srivastava, M. (2017). A review on medicinal properties of Centella asiatica. Asian Journal of Pharmaceutical and Clinical Research, 10(10), 69. https://doi.org/10.22159/ajpcr.2017. v10i10.20760

Prasad, A, Dhawan, S. S., Mathur, A. K., Prakash, O., Gupta, M. M., Verma, R. K., Lal, R. K., \& Mathur, A. (2014). Morphological, chemical and molecular characterization of Centella asiatica germplasms for commercial cultivation in the Indo-Gangetic plains. Natural Product Communications, 9(6), 779-784.

Prasad, Archana, Singh, M., Yadav, N. P., Mathur, A. K., \& Mathur, A. (2014). Molecular, chemical and biological stability of plants derived from artificial seeds of Centella asiatica (L.) Urban-An industrially important medicinal herb. Industria/ Crops and Products, 60, 205-211. https:// doi.org/10.1016/j.indcrop.2014.06.022

Radhika, K., Sumer, S., Gopinath, S. M., \& Patil, A. G. M. (2012). A study on assessment of genetic diversity and relationships of medicinal plants using RAPD markers. Global Journal of Research on Medicinal Plants \& Indigenous Medicine, 1(12), 678.

Rakotondralambo, S. O. R., Lussert, A., Rivallan, R., Danthu, P., Noyer, J. L., \& Baurens, F. C. (2012). Microsatellite markers isolated from the wild medicinal plant Centella asiatica (Apiaceae) from an enriched genomic library. American Journal of Botany, 99(4), 26-29. https:// doi.org/10.3732/ajb.1100441

Rakotondralambo, S. O. R., Rodier-Goud, M., Rivallan, R., Lussert, A., Danthu, P., de Lamotte, F., Ralambofetra, E., Ramavovololona, P., Noyer, J. L., \& Baurens, F. C. (2013). Insight into the biology, genetics and evolution of the Centella asiatica polyploid complex in Madagascar. Industrial Crops and Products, 47(MAY), 118-125. https://doi.org/10.1016/j.indcrop.2013.02.022

Rao, B. R. R. (2016). Genetic diversity, genetic erosion, conservation of genetic resources, and cultivation of medicinal plants. In Genetic Diversity and Erosion in Plants (pp. 357-407). Springer.

Ravi, C. S., Umesha, K., HimaBindu, K., Shetty, G. R., \& Kumar, G. S. A. (2019). Collection and morphological variability in ecotypes of Indian Pennywort (Centella asiatica L.) of Hill zone of Karnataka, India. International Journal of Current Microbiology and Applied Sciences, 8(9), 994-1008. https://doi.org/10.20546/ijcmas.2019.809.117

Ražná, K., Hlavačková, L., Bežo, M., Žiarovská, J., Habán, M., Sluková, Z., \& Pernišová, M. (2015). Application of the RAPD and miRNA markers in the genotyping of Silybum marianum (L.) Gaertn. Acta Fytotechnica et Zootechnica, 18(4), 83-89. https://doi.org/10.15414/ afz.2015.18.04.83-89
Rohini MR, Anuradha Sane, Ravish Chaudhary, H. K. (2019). Molecular characterization and DNA fingerprinting of Centella asiatica using SSR markers. International Journal of Chemical Studies, 7(1), 705-710.

Ruan, Y., Mo, R. H., Li, M., Huang, L. Q., Luo, Y., Li, X. Y., Zhou, J., \& Wu, Y. S. (2008). Molecular characters of Centella asiatica found with RAPD technology. Zhong Yao Cai, 31(7), 970-973.

Sahu, J., Das Talukdar, A., Devi, K., Choudhury, M. D., Barooah, M., Modi, M. K., \& Sen, P. (2015). E-Microsatellite markers for Centella asiatica (Gotu Kola) Genome: Validation and cross-transferability in apiaceae family for plant omics research and development. Omics-a Journal of Integrative Biology, 19(1), 52-65. https://doi.org/10.1089/ omi.2014.0113

Sakthipriya, M., Vishnu, S. S., Sujith, S., Kumar, P. R., \& Sabu, K. K. (2018). Analysis of genetic diversity of Centella asiatica using SSR markers. International Journal of Applied Sciences and Biotechnology, 6(2), 103-109. https://doi.org/10.3126/ijasbt.v6i2.19583

Sangwan, R. S., Tripathi, S., Singh, J., Narnoliya, L. K., \& Sangwan, N. S. (2013). De novo sequencing and assembly of Centella asiatica leaf transcriptome for mapping of structural, functional and regulatory genes with special reference to secondary metabolism. Gene, 525(1), 58-76. https://doi.org/10.1016/j.gene.2013.04.057

Sarwat, M., \& Yamdagni, M. M. (2016). DNA barcoding, microarrays and next generation sequencing: recent tools for genetic diversity estimation and authentication of medicinal plants. Critical Reviews in Biotechnology, 36(2), 191-203. https://doi.org/10.3109/0738855 1.2014.947563

Satheesan, J., \& Sabu, K. K. (2019). Centella asiatica (L.) Urb., an Endowment from Traditional Medicine. Medicinal Plants: Chemistry, Pharmacology, and Therapeutic Applications, 43. https://doi. org/10.1201/9780429259968-3

Semagn, K., Bjørnstad, Å., \& Ndjiondjop, M. N. (2006). An overview of molecular marker methods for plants. African Journal of Biotechnology, 5(25), 2540-2568.

Sharma, A., Kumar, N., \& Mishra, I. G. (2018). Role of molecular marker in the genetic improvement of the medicinal and aromatic plants. In Biotechnological Approaches for Medicinal and Aromatic Plants (pp. 557-567). Springer.

Srivastava, S., Srivastava, S., \& Mishra, N. (2009). Genetic markers - A cutting-edge technology in herbal drug research. Journal of Chemical and Pharmaceutical Research, 1(1), 1-18.

Subositi, D., Widodo, H., \& Supriyati, N. (2016). Skrining Marka ISSR untuk Autentikasi Pegagan (Centella asiatica [L.] Urb.) (Screening of ISSR Markers for Pegagan [Centella asiatica [L.] Urb] Authentication). Buletin Plasma Nutfah (BPN), 22(1), 49-54. https://doi.org/10.21082/ blpn.v22n1.2016.p49-54

Sudhakaran, M. V. (2017). Botanical Pharmacognosy of Centella asiatica (Linn.) Urban. Pharmacognosy Journal, 9(4), 546-558. https://doi. org/10.5530/pj.2017.4.88

Szcześniak, M. W., Deorowicz, S., Gapski, J., Kaczyński, Ł., \& Makałowska, I. (2012). miRNEST database: an integrative approach in microRNA search and annotation. Nucleic Acids Research, 40(D1), D198-D204. https://doi.org/10.1093/nar/gkr1159

Tan, S.-H. (2017). Morphological and biochemical characteristics on different accession of pegaga. Indian Journal of Science and Technology, 10(2), 1-5. https://doi.org/10.17485/ijst/2017/v10i2/110370

Tandon, P., Kumaria, S., \& Nongrum, L. (2009). Conservation and management of plant genetic resources of Northeast India. 8(1), 29-34.

Thomas, M. T. (2010). Biosystematic studies on the taxa of Hydrocotyle L, and Centella L. occurring in Peninsular India with special reference to intraspecific variants of Centella asiatica (L.) Urb. Dissertation, University of Kerala (JNTBGRI).

Vinolina, N. S., Siregar, L. A. M., \& Justin, A. (2012). Morphology of leaves and content of secondary metabolites asiaticoside in some accession of pegagan (Centella asiatica I. Urban) in North Sumatera. 2(1), 22-24.

Welsh, J., \& McClelland, M. (1990). Fingerprinting genomes using PCR with arbitrary primers. Nucleic Acids Research, 18(24), 7213-7218. https://doi.org/10.1093/nar/18.24.7213

Wheeler, D. L., Barrett, T., Benson, D. A., Bryant, S. H., Canese, K., Chetvernin, V., Church, D. M., DiCuccio, M., Edgar, R., \& Federhen, S. (2007). Database resources of the national center for biotechnology information. Nucleic Acids Research, 36(S1), D13-D21. https://doi. org/10.1093/nar/gkx1095

Williams, J. G. K., Kubelik, A. R., Livak, K. J., Rafalski, J. A., \& Tingey, S. V. 
(1990). DNA polymorphisms amplified by arbitrary primers are useful as genetic markers. Nucleic Acids Research, 18(22), 6531-6535. https://doi.org/10.1093/nar/18.22.6531

Wootton, J. C. (2002). Development of HerbMed ${ }^{\circledR}$ : An interactive, evidence-based herbal database. In Advances in Phytomedicine (Vol. 1, pp. 55-60). Elsevier.

Yanuar, A., Mun'im, A., Lagho, A. B. A., Syahdi, R. R., Rahmat, M., \& Suhartanto, H. (2011). Medicinal plants database and three dimensional structure of the chemical compounds from medicinal plants in Indonesia. International Journal of Computer Science Issues, 8(1), 180-183.

Zeng, S., Xiao, G., Guo, J., Fei, Z., Xu, Y., Roe, B. A., \& Wang, Y. (2010). Development of a EST dataset and characterization of EST-SSRs in a traditional Chinese medicinal plant, Epimedium sagittatum (Sieb. Et Zucc.) Maxim. BMC Genomics, 11(1), 1-11. https://doi. org/10.1186/1471-2164-11-94

Zhang, B., \& Wang, Q. (2015). MicroRNA-based biotechnology for plant improvement. Journal of Cellular Physiology, 230(1), 1-15. https:// doi.org/10.1002/jcp.24685

Zhang, X. G., Han, T., He, Z. G., Zhang, Q. Y., Zhang, L., Rahman, K., \& Qin, L. P. (2012). Genetic diversity of Centella asiatica in China analyzed by inter-simple sequence repeat (ISSR) markers: Combination analysis with chemical diversity. Journal of Natural Medicines, 66(1), 241-247. https://doi.org/10.1007/s11418-011-0572-4

Zhang, Y., Yan, H., Jiang, X., Wang, X., Huang, L., Xu, B., Zhang, X., \& Zhang, L. (2016). Genetic variation, population structure and linkage disequilibrium in Switchgrass with ISSR, SCOT and ESTSSR markers. Hereditas, 153(1), 1-12. https://doi.org/10.1186/ s41065-016-0007-Z

Zhang, Z., Yu, J., Li, D., Zhang, Z., Liu, F., Zhou, X., Wang, T., Ling, Y., \& Su, Z. (2010). PMRD: plant microRNA database. Nucleic Acids Research, 38(S1), D806-D813. https://doi.org/10.1093/nar/gkp818

Zietkiewicz, E., Rafalski, A., \& Labuda, D. (1994). Genome fingerprinting by simple sequence repeat (SSR)-anchored polymerase chain reaction amplification. Genomics, 20(2), 176-183. https://doi.org/10.1006/ geno.1994.1151 